\title{
HUMPHREY DYSON.
}

OOKS bearing their owner's names
have mostly a certain amount of in-
terest, sometimes historical, sometimes
personal. Readers in a good many of
of our large libraries must have been
struck by a modest signature Hum: Dyson: Not:
Pub: on Sixteenth and Seventeenth century books.
Some of them bear his book-stamp.
There seems to be nothing recorded about Dyson
save Mr. Hazlitt's notice of him in his 'Roll of
Honour, which states that he was a notary public
and historical antiquary, famous for collecting early
English literature and that his books were inherited
by Richard Smith, Secondary of the Poultry. Smith
did not inherit Dyson's books, but that a great
number of them formed the nucleus of his col-
lection cannot be doubted. Mr. Duff in 'THE
LiBRARY' for April, I 907 , has already said all that
can now be discovered about Smith's collection.
It is hoped that he will one day write on that of
Dyson. Here I am not so much concerned with
Dyson's books as desirous of placing on record a few details as to his parentage, life and family. His father I take to be a certain Christopher Dyson, Citizen and Wax-chandler of London, who in his will, proved in I609, leaves to his wife Mary twothirds of his property, and to his two youngest 
daughters, Judith and Susanna, the remaining third. His wife Mary was his executrix; the overseers of his will were two of his neighbours Mr. Thomas Savage and Mr. Francis Roberts. The will was witnessed by Thomas Savadge and Humfrey Dyson, Notary Publique. The probate act gives the further information that he lived in St. Albans Wood Street parish. My reasons, in addition to their appearance together as testator and witness, for assuming Christopher to be Humfrey's father are, that Humfrey Dyson, as will be seen from his own will below, was also a Waxchandler, probably by patrimony, and mentions a sister Susan. There can be no shadow of doubt that the Humphrey Dyson the Wax-chandler is the same person as the Humfrey Dyson whose signature appears on so many books and pamphlets in most of our large libraries. On the last day of February, 1632, the will of Humphrey Dyson, Citizen and Wax-chandler of London was proved. He desires, after expressing the usual pious wishes with which it was usual in those days to preface one's last will and testament, to be buried privately without any pomp. His two eldest daughters Anne and Elizabeth have already been advanced in marriage and the money that has been given to them is to be put into 'Hotchpott' with his personal estate according to the custom of the City of London. The marriage portions thus spoken of were, Anne $£_{5} 6 \quad 5$ s., and Elizabeth $£ 80$. The bequests may be summarized as follows:

One third of my estate among all my sixe children, vizt., Anne, Elizabeth, Thomas, Edward, Mary, and 
Tabitha. Elizabeth my now wife was joint purchaser with me of my capital messuage etc. in Wandsworth, co. Surrey which I esteem to be worth $£ 20$ yearly, this is to be taken as part of the 660 per annum secured to her. To my grandchild Elizabeth Daines if she shall survive my wife £20. To my grandchild Martha Clarke £20. To my dearely beloved wife Elizabeth Dyson the somme of twentie pounds to buy her mourninge apparrell and other such like necessaries. Item I give vnto her every yeare yearely, on new yeare's daie for soe long tyme as she shall continue my widow and not be married for a new yeares gift and as a remembrance of my love two new tiffinie ruffes or fortie shillings in money at her owne free choice. Alsoe I give unto her on new yeares daie wch shall happen in every third yeare after my decease, if she shall soe long continue and remaine my widowe and not be married a new beaver hatt or three pounds tenne shillings. To my godson Humfrey Blackborne towards his binding forth apprentice the sum of $40 \mathrm{~s}$. To my poor kinsman Christopher Jolles and to his sister Jane 40s. each. To my eldest apprentice William Fittonn the last year of his term and to my youngest apprentice Joseph Ferrett the two last years of his term, and I doe hereby charge them to aid my executor in orderinge and layinge vpp of all draughts, presidents, and papers belonging to my profession to thend that they maie be safely kept and preserved, yet neverthelesse for the betteringe of theire owne understandinge and for their greater ease in theire trade and profession (if they follow my calling) my Executors shall permitt them at all reasonable and seasonable tymes to have the free use of any of them, they maie take copies of such of them as they shall thinke fitt desiring god to give them his grace. James Johnson to have his silver cup back on paying 40 . by 5 s. a quarter. My Son-in-law Richard Daines not to be charged on his bond. To the Company of Waxchandlers of City of London of whom I am a member a silver and gilt cup 
with a cover valued at $£ 5$ with my name engraven thereon. After my wife's death my estate to be sold by my friend William Jumper and the proceeds divided among my children. To my sisters Rose Jeeve and Susan Twistleton 40s. each for rings. To William Jumper my executor a silver gilt cup valued at $\oint_{1}$ ro knowing that he will administer my estate from conscience and not for the gift. I earnestly desire him to have a care to put of and sell my bookes to the most profitt that he can. I give and bequeath unto my noble friend Sir William Paddy, Knight, to be by him put and given to the library of St. Johns College in Oxford my Statutes at large printed in two great volumes of large paper. To my son Daines my blacke cloke faced with taffaty and my sattin suite. To Elizabeth Winchecombe my maidservant Ł3. Mr. Robert Bateman to have the best pair of gloves in my study. My wife to have the great bible.

The will is dated 7 th January, $163^{2}$ (O.S.) and is witnessed by Ralfe Hartley, Katherin Sutton, Joseph Ferrett, Katherine Cotton, and Rebecca Strugnell. The signature agrees with Dyson's usual signature to wills as notary public and with that on the books. His wife was the daughter of Thomas Speght of the Precinct of St. James in the Wall, London, gentleman, for Speght bequeathed on 27th February, I620, 'To my daughter Elizabeth the wife of Humfrey Dison $£ 40$,' and the witnesses to the will are 'Hum. Dyson, Notary publique, the marke of Elizabeth Dyson.' Speght was an editor of Chaucer and Lydgate, and a schoolmaster, and Dyson's wife seems to have been a daughter by a second wife Anne. Sir William Paddy who lived in Wood Street, died at the age of $8 \mathrm{I}$, the year after Dyson, leaving his Library to St. Johris 
College, Oxford, in the chapel of which he desired to be buried. The Mr. Robert Bateman to whom Dyson left the gloves in his study was apparently a bookseller who flourished in London at that time and for some years after. Joseph Ferrett afterwards became a notary public and one of his first clients was his master's old friend, Sir William Paddy, whose will he made on $23^{\text {rd }}$ August, I 634. The name of the other apprentice has not been met with. The clause in the will relating to precedents and drafts, the apprentice following the profession of notary, the signatures and the wife's christian name in both cases alike furnish reasonable proofs that Dyson the wax-chandler and Dyson the notary public, book collector and bibliographer are one and the same person. The reverend gentlemen in whose care the parish registers of the different parishes are, do not readily furnish facilities for search and a letter to the clerk of the Wax-chandler's society met with no answer.

The only other records of the period I have examined are the State Papers Domestic, Patent and Close Rolls. The Close Rolls record the purchase of Dyson's dwelling house and some land in Wandsworth. On 24th May, 4. Charles I., an indenture is made between Sir Thomas Freke of Shrawton, co. Dorset, Knight, and Humfrey Dyson, Citizen and Wax-chandler of London, reciting that on the 18th March, 17. James I., John Mayle of London, Esq., granted to Sir Thomas his messuage and house wherein he then dwelt. Sir Thomas now grants them on payment of $£ 60$ to Dyson who now dwells in them. Dyson and Freke are 
again, on 22nd April, 5. Charles I., parties with others to carry out the provisions of a former indenture and on the same date there is an indenture $r$ ween John Monger, citizen and cordwainer of don, a son of Benjamin Monger, late of London, and Mary wife of John on one part and Humphrey Dyson, citizen and wax-chandler of London and Elizabeth his wife on the other part, for the purchase of lands in Wandsworth for $£ 300$. In the State Papers Domestic of Charles I., Vol. 240 (25) there is an account of a dispute about a will in which Dyson appears and corroborates evidence given to the effect that the wife of the deceased asked a Dr. Spicer to speak to Humphrey Dyson a scrivener to come and make the decedant's will. Dr. Spicer did so, but Dyson having enquired in what case the decedent was, made answer that he would not make a dead man's will and refused to go. In spite of this evidence in favour of the plaintiffs, judgment was given for the defendant. Dyson had an extensive business. During the latter part of Elizabeth's reign, the whole of James's, and till within a few weeks of his death, his name is met with constantly as the drawer of wills and other documents. He was engaged in a famous lawsuit in the printing world. His son Thomas died the year after his father, unmarried, he is described as citizen and wax-chandler, thus following in the steps of his father and grandfather. His father's affairs had not been settled at his death. Dyson's son Edward described as citizen and apothecary died in the early part of 1649 , leaving a wife Arabella and a daughter Mary and probably a 
posthumous child. His daughter Elizabeth married Richard Danes and had at least two children Elizabeth and Hester, and his daughters Anne, Mary, and Tabitha married men called Goddard, Clarke, and Butler respectively. He had one other grandchild, Martha Clarke. William Jumper, Dyson's executor, died in March, 1642 , and was probably buried in St. Lawrence Jewry where he lived. The parish in which Dyson's father lived, St. Alban, Wood Street, Dyson's parish St. Olave, Old Jewry, Coleman Street Ward, and St. Lawrence Jewry are all contiguous.

The only publications bearing Dyson's name are: 'a Booke containing all such Proclamations as were published during the Rayne of the late Queene Elizabeth,' London, 1618, fol. (this is a list), and Stow's 'Survey of London,' I 633, edited in conjunction with Munday and others. Many of Dyson's books are to be found at the British Museum, several are at Dr. Marsh's library, Dublin, and some were recently sold at Sotheby's. There are five sets of proclamations collected by him, in the British Museum, Privy Council Office, Bodleian, Queen's College, Oxford, and the Society of Antiquaries. In the last set there are many MS. ones, each certified by Dyson as having been seen and compared with the original. In the last half of the Seventeenth century there was a Charles Dyson of Tottenham High Cross, gentleman, who "was possessed of a large Study of very valuable Bookes of the Law and in other faculties and Sciences' and was also possessed of 'Stocks and Shares in the King's Printing House.' This, with the informa- 


\section{HUMPHREY DYSON.}

tion that he had children named Joshua, Susanna, Elizabeth, Lucy, Charles, and Mary, is taken from a Chancery Suit. The names in italics are common names but they were in use in Dyson's family. There may be no connection between the two men, but the coincidences are curious.

R. L. Steele. 